\title{
ANALISIS OPTIMASI KETELITIAN DIMENSI, KEKASARAN PERMUKAAN DAN LAJU KEAUSAN ELEKTRODE PADA PROSES ELECTRIC DISCHARGE MACHINING DENGAN METODE TAGUCHI MULTI RESPON
}

\author{
Edy Sulistiyawan \\ Dosen Program Studi Statistika Universitas PGRI Adi Buana (UNIPA) Surabaya \\ edy.sulistiyawan@gmail.com
}

\begin{abstract}
ABSTRAK
Electrical Discharge Machining (EDM) adalah mesin non konvensional yang bekerja berdasarkan terjadinya loncatan bunga api secara periodic dari electrode ke benda kerja. Proses pengerjaan dengan EDM mempunyai beberapa keunggulan jika dibandingkan dengan proses-proses yang lain. PADA enelitian ini dilakukan pada mesin EDM TYPE CHMER 50 MP di PT. HAY-SEN. Variabel-variabel bebas yang diteliti pada penelitian ini merupakan faktor-faktor yang dapat dikendalikan pada setting mesin yaitu arus, on-time pulse, dan tegangan, serta masing-masing variabel mempunyai tiga taraf pengamatan. Percobaan utama dilaksanakan dengan menggunakan rancangan OA $\mathrm{L}_{27}$. Analisis data dilakukan dengan pendekatan konvensional Taguchi untuk optimasi respon satu per satu dan aplikasi prosedur TOPSIS untuk memperoleh suatu standart setting yang dapat mengoptimumkan ketiga respon secara sekaligus. Hasil penelitian diperoleh bahwa respon kekasaran permukaan, laju keausan elektrode dan ketelitian dimensi dipengaruhi oleh faktor-faktor utama yaitu arus, on-time pulse, dan tegangan serta interaksi dua faktor yaitu antara arus dan tegangan. Kombinasi taraf faktor yang menghasilkan ketiga respon yang optimum adalah setting mesin dengan arus $3 \mathrm{~A}$, on-time pulse $100 \mu \mathrm{m}$ dan tegangan 70 volt. Sedangkan estimasi harga kekasaran permukaan optimum yang diperoleh adalah sebesar $1.24 \mu \mathrm{m}$, dan interval kepercayaan $90 \%$ diperoleh range antara $1.17 \mu \mathrm{m}$ sampai $1.33 \mu \mathrm{m}$. Untuk respon laju keausan elektrode diperoleh estimasi harga yang optimum sebesar $0.0096 \mathrm{~mm}^{3} / \mathrm{dtk}$, dan dengan interval kepercayaan $90 \%$ diperoleh range antara $0.0078 \mathrm{~mm}^{3} / \mathrm{dtk}$ sampai $0.0018 \mathrm{~mm}^{3} / \mathrm{dtk}$. Untuk respon ketelitian dimensi diperoleh estimasi harga yang optimum sebesar $0.0354 \mathrm{~mm}$, dan interval estimasi harga yang optimum sebesar $0.0354 \mathrm{~mm}$, dan interval kepercayaan $90 \%$ diperoleh range antara $0.0325 \mathrm{~mm}$ sampai $0.0387 \mathrm{~mm}$.
\end{abstract}

Kata Kunci : Taguchi Multirespon, Electrical Discharge Machining, Optimasi respon, Ketelitian dimensi, Kekasaran permukaan, Laju keausan elektrode.

\section{A. Pendahuluan}

Pada pernbuatan dies dengan proses EDM perautan tidak hanya terjadi pada benda kerja akan tetapi juga terjadipada elektrode (tool). Hal ini akan rnenyebabkan terjadinya keausan pahat (elektrode). Terjadinya keausan pacta electrode tersebut akan rnengakibatkan ketelitian dimensi yang dihasilkan 
berkurang disarnping itu keausan pahat yang terjadi konfigurasinya tidak dapat ditentukan sehingga ini akan dapat rnernpertinggi kekasaran perrnukaan yang dihasilkan. Dan kedua hal tersebut tidak diinginkan terjadi pada proses tersebut sehingga perlu diperkecil.

Proses pengerjaan dengan EDM mempunyai beberapa keunggulan jika dibandingkan dengan proses-proses yang lain. Keunggulan-keunggulan tersebut antara lain :

1. Dapat mengerjakan benda kerja yang sangat keras terutama material dengan karbon tinggi.

2. Tidak terjadi kontak secara langsung antara benda kerja dengan elektrode sehingga mungkinkan pengerjaan benda-benda kerja yang tipis.

3. Mampu mengerjakan benda kerja yang berbentuk kompleks.

4. Meskipun pengerjaannya berdasarkan panas akan tetapi panas yang terjadi tidak merambat keseluruh benda kerja.

5. Produk yang dihasilkan dari proses ini mempunyai kepresisian yang lebih baik jika di bandingkan dengan produk proses yang lain.

6. Hampir semua pekerjaan pada mesin konvensional dapat dikerjakan dengan proses ini.

Permasalahan yang harus diselesaikan dalam penelitian ini adalah pertama diketahuinya pengaruh variabel proses yang signifikan terhadap laju keausan elektrode, kekasaran permukaan dan ketelitian dimensi pada proses EDM, kedua diketahuinya setting variabel proses yang optimal secara serentak sehingga mengoptimalkan proses dan dihasilkan laju keausan elektrode, kekasaran dan ketelitian dimensi dan ketiga diketahui nilai taksiran laju keausan elektrode, kekasaran permukaan dan ketelitian dimensi yang optimal yang bisa dicapai.

Penelitian ini bertujuan untuk untuk mengetahui pengaruh variabel proses yang signifikan terhadap laju keausan elektrode, kekasaran permukaan dan ketelitian dimensi pada proses EDM, dan mengetahui setting variabel proses yang optimal secara serentak sehingga mengoptimalkan proses dan dihasilkan laju keausan elektrode, kekasaran dan ketelitian dimensi, mengetahui nilai taksiran laju keausan elektrode, kekasaran permukaan dan ketelitian dimensi yang optimal yang bisa dicapai. Manfaat yang diharapkan dari hasil penelitian ini adalah memberikan masukan informasi tentang setting pemesinan yang tepat untuk kondisi material tertentu pada proses pembuatan dies dengan menggunakan mesin EDM (Electrical DischargeMachining) dan selanjutnya dapat diterapkan dengan cara yang sama untuk kondisi material dan proses pemesinan lainnya. Dalam penelitian ini, peneliti membatasi permasalahan pada penelitian mesin EDM jenis CHMER 50MP dan tidak membahas tentang rangkaian listriknya.

\section{B. Tinjauan Pustaka}

\section{Tinjauan Mesin Electrical Discharge Machining}

Proses perautan yang terjadi pada proses EDM dilakuakn sejumlah loncatan bunga api listrik yang terjadi pada celah antara electrode dan benda kerja, yang terjadi secara periodik. Perbedaan yang mendasar antara proses EDM dengan electrical machining adalah pada besarnya tegangan antara electrode dan benda kerja terendam dalam suatu fluida dielektrik. Untuk dapat menghasilkan loncatan 
bunga api listrik, maka besarnya tegangan yang terjadi antara elektrode dan benda kerja harus melampaui breakdown voltage dari gap tersebut. Besarnya breakdown voltage tersebut sangat tergantung pada :

1. Jarak pada dua posisi terdekat antara elektrode dan benda kerja.

2. Sifat isolator dari fluida dielektrik yang digunakan.

3. Tingkat polusi yang terjadi pada celah dielektrikum tersebut.

Proses terjadinya saluran ion dan loncatan bunga api pada EDM adalah sebagai berikut :

1. Dengan adanya medan listrik antara pahat (elektrode) dengan benda kerja, elektron elektron bebas yang terdapat pada permukaan elektrode (katoda) akan tertarik menuju anoda (benda kerja). Dalam pergerakkannya menuju ke anoda, maka elektron-elektron yang berenergi kinetis tinggi ini akan bertumbukan dengan molekul-molekul yang ada pada fluida dielektrik.

2. Didalam proses tumbukan antara electron bebas dengan molekul dielektrik tersebut, maka akan terbentuk electron baru yang juga ikut bergerak sesuai dengan muatannya. Dan akhirnya akan terbentuklah saluran ion.

3. Dengan saluran ion tersebut maka tahanan listrik pada gap akan menjadi sangat rendah sehingga menyebabkan terjadinya pelepasan energi listrik dalam waktu yang singkat sekali dalam hal ini berupa loncatan bunga api listrik.

\section{Kekasaran Permukaan}

Pada dasarnya kekasaran permukaan merupakan ketidakteraturan konfigurasi permukaan pada suatu benda atau bidang. Selain itu kekasaran permukaan masih dapat dibedakan lagi menjadi dua, yaitu :

1. Kekasaran permukaan ideal : merupakan kekasaran permukaan yang diperoleh dengan kondisi ideal dimana hanya dipengaruhi oleh variabel permesinan saja. Pada proses EDM kekasaran permukaan ideal dipengaruhi oleh voltage, kuat arus dan on-time pulse. Kekasaran permukaan produk pada proses EDM juga dipengaruhi oleh arus listrik yang mengalir pada alat tersebut, karena proses pengerjaan pada proses EDM tergantung pada besarnya energi listrik yang diubah menjadi energi panas.

2. Kekasaran permukaan natural : merupakan kekasaran permukaan yang dipengaruhi oleh ketidakteraturan selama proses pemesinan, kesalahan operator dan getaran mesin.

\section{Ketelitian Dimensi}

Ketelitian dimensi didefinisikan sebagai perswesuaian antara hasil pengukuran dengan suatu harga yang dianggap benar dari objek yang diukur. Perbedaan antara harga yang diukur dengan harga yang dianggap benar disebut kesalahan sistematis, dan apabila harga kesalahan sistematis semakin kecil 


\section{Fluida Dielektrik}

Fluida dielektrik memegang peranan yang sangat penting didalam proses EDM, hal ini disebabkan karena fungsi yang dimiliki oleh fluida dielektrik tersebut. Fungsi fluida dielektrik padaproses EDM antara lain :

1. Sebagai pendingin pahat dan benda kerja.

2. Dalam keadaan terionisasi fluida dielektrik ini adalah semacam konduktor sehingga memungkinkan terjadinya loncatan bunga api listrik.

3. Sebagai pembawa pergi geram-geram yang terbentuk dari proses tersebut.

Fluida yang sering digunakan untuk proses ini antara lain : air (Aqua-destilasi), minyak mineral, kerosene, dan lain-lain.

\section{Tinjauan Statistika}

Pada umumnya kesulitan yang sering timbul pada pengendalian kualitas adalah memperbaiki pengaturan taraf-taraf parameter proses input untuk memenuhi spesifikasi output. Akan tetapi apabila pengaturan karakteristik kualitas dilakukan sedini mungkin maka spesifikasi yang diharapkan dalam pengendalian kualitas akan tercapai. Untuk itu perlu dilakukan optimasi proses sejak awal, maksudnya mulai dari pembuatan alat yang digunakan pada proses produksi sampai pada proses produksi yang berkelanjutan, sehingga dihasilkan suatu produk yang berkualitas. Pendekatan dengan menggunakan metode taguchi memberikan konstribusi yang besar dalam pengembangan proses pengendalian kualitas di dunia industri. Selama ini metode Taguchi, aplikasinya hanya pada optimasi respon tunggal. Sedangkan untuk kasus multirespon sangatlah terbatas. Meskipun demikian, beberapa ilmuwan telah berusaha mengembangkan metodemetode untuk menyelesaikan masalah ini.

Pada tahun 1995 Lee-lng Tong dan Chao-Ton Su membuat prosedur TOPSIS dan memperkenalkanya melalui artikel yang berjudul "Qptimising Multirespons Problems in Taguchi Methods by Fuzzy Multiple Attribute Decision Making" yang dimuat di jurnal Quality and Reliability Engineering International volume 13 tahun 1997. Prosedur ini dapat menyelesaikan masalah-masalah multidimensi seperti mencaro kombinasi atau setting optimum dari suatu proses permesinan.

\section{Rancangan Faktorial Lengkap $3^{3}$}

Rancangan faktorial lengkap didefinisikan sebagai rancangan dari percobaan sekumpulan faktor dimana semua faktor tertentu dikombinasikan dengan semua taraf sebuah faktor-faktor lainnya yang terlibat dalam eksperimen. Dengan demikian rancangan ini sangat tepat digunakan sebagai rancangan percobaan awa1 yang ditunjukkan untuk mempelajari seluruh efek interaksi yang ada antar faktor-faktor utama. Dalam penelitian ini tidak dilakukan percobaan awal, akan tetapi berdasarkan referensi yang menyatakan adannya interaksi antar faktor-faktor utama.

\section{Pendekatan Metode Taguchi}

Pada tahun 1940 DR. Genechi Taguchi memperkenalkan beberapa konsep statistik baru yang telah terbukti sebagai alat yang sangat berperan dalam pengembangan kualitas. DR. Genechi Taguchi juga memperkenalkan pendekatan 
metode yang dilandasi oleh tiga komsep mendasar, yang dikenal dengan Falsafah Taguchi, ketiga konsep tersebut yaitu :

1. Kualitas harus didesain ke dalam produk dan tidak sekedar melakukan inspeksi terhadapnya.

2. Kualitas adalah jangkauan terbaik dalam meminimumkan simpangan dari target tertentu.

3. Biaya kulaitas harus diukur sebagai fungsi simpangan dari standar tertentu dan kerugian harus diukur dalam keseluruhan sistem.

\section{Kelebihan Metode Taguchi :}

1. Rancangan percobaan Taguchi efisien karena memungkinkan untuk melaksanakan percobaan yang melibatkan banyak faktor tetapi jumlah unit percobaan yang diperlukan relatif kecil.

2. Rancangan percobaan Taguchi memungkinkan diperolehnya suatu proses yang menghasilkan produk lebih konsisten dan kurang sensitif (robust) terhadap variabilitas yang disebabkan oleh faktor-faktor yang tidak dapat dikendalikan (noise).

3. Penggunaan metode taguchi menghasilkan kesimpulan mengenai faktorfaktor yang berpengaruh terhadap suatu reapon, dan kesimpulan mengenai taraf-taraf faktor terbaik yang akan mengahasilkan respon optimum.

\section{Kekurangan Metode Taguchi :}

Rancangan percobaan Taguchi mempunyai struktur alias yang sangat kompleks, dimana terdapat rancangan yang mengorbankan pengaruh interaksi dan ada pula rancangan yang membaurkan pengaruh utama dan pengaruh interaksi dua faktor. Hal ini cukup berbahaya apabila ternyata pengaruh interaksi cukup signifikan. Untuk mengatasinya harus dilakukan pemilihan rancangan percobaan secara hati-hati dan sesuai dengan tujuan penelitian.

\section{Prinsip Kerja Metode Taguchi}

Suatu keluarga matrik eksperimen fraksi faktorial yang berguna dalam mereduksi banyaknya percobaan dari jumlah semestinya telah dikembangkan oleh Taguchi. Rancangan tersebut mengambil fraksi eksperimen yang dibentuk dalam kolom-kolom orthogonal yang disebut Orthogonal Arrays (OA). Kolom-kolom OA digunakan untuk mengestimasi semua efek faktor utama dan beberapa (tidak semua) efek interaksi. OA dirumuskan dalam bermacam-macam tabel OA yang diberikan simbul $\mathrm{L}_{\mathrm{k}}$. Huruf $\mathrm{k}$ menyatakan banyaknya baris yang sama dengan banyaknya eksperimen yang dilakukan. Sehingga dalam penelitian ini jika dilakukan pengamatan terhadap tujuh faktor utama A, B, C, D, E, F, dan G yang masing-masing mempunyai 2 taraf pengamatan, maka pengamatan mempunyai tujuh derajat bebas sehingga digunakan matriks $\mathrm{OA} \mathrm{L}_{8}$ seperti pada tabel berikut : 
Tabel 1. Matriks $\mathrm{OA} \mathrm{L}_{8}$

\begin{tabular}{|c|c|c|c|c|c|c|c|}
\hline & \multicolumn{7}{|c|}{ Nomor Colom } \\
\hline \multirow{3}{*}{ PERCoBAAN } & 1 & 2 & 3 & 4 & 5 & 6 & 7 \\
\cline { 2 - 8 } & \multicolumn{7}{|c|}{ Faktor } \\
\cline { 2 - 8 } & $\mathrm{A}$ & $\mathrm{B}$ & $\mathrm{C}$ & $\mathrm{D}$ & $\mathrm{E}$ & $\mathrm{F}$ & $\mathrm{G}$ \\
\hline 1 & 1 & 1 & 1 & 1 & 1 & 1 & 1 \\
\hline 2 & 1 & 1 & 1 & 2 & 2 & 2 & 2 \\
3 & 1 & 2 & 2 & 1 & 1 & 2 & 2 \\
\hline 4 & 1 & 2 & 2 & 2 & 2 & 1 & 1 \\
\hline 5 & 2 & 1 & 2 & 1 & 2 & 1 & 2 \\
\hline 6 & 2 & 1 & 2 & 2 & 1 & 2 & 1 \\
\hline 7 & 2 & 2 & 1 & 1 & 2 & 2 & 1 \\
\hline 8 & 2 & 2 & 1 & 2 & 1 & 1 & 2 \\
\hline
\end{tabular}

Untuk menguraikan sebuah kondisi dimana pengaruh satu faktor atas respon atau hasil pengamatan bergantung pada kondisi faktor yang lain digunakan interaksi. Dua faktor A dan B dikatakan berinteraksi (AxB) apabila efek perubahan dalam faktor A menentukan efek faktor B dan sebaliknya. Dan apabila dilakukan pengamatan terhadap tiga faktor utama A,B,C yang masing-masing bertaraf tiga dan efek interaksi dua faktor $\mathrm{AxB}, \mathrm{AxC}$, dan $\mathrm{BxC}$, maka percobaan mempunyai 18 derajat bebas. Matrik OA yang sesuai adalah yang OA 3-taraf dengan jumlah baris minimum sama dengan 18 , yaitu $\mathrm{L}_{18}$ atau $\mathrm{L}_{27}$. Dalam penelitian ini digunakan rancangan $\mathrm{OA} \mathrm{L}_{27}$ dengan penempatan faktor-faktor utama dan interaksi disajikan dalam tabel berikut :

Tabel 2. Penempatan Faktor Utama dan Interaksi pada Matriks OA $\mathrm{L}_{27}$

\begin{tabular}{|r|c|}
\hline \multirow{2}{*}{ Kolom } & $\begin{array}{c}\text { Penempatan Faktor } \\
\text { Utama dan Interaksi }\end{array}$ \\
\hline 1 & A \\
\hline 2 & B \\
\hline 3 & AXB \\
\hline 4 & AXB \\
\hline 5 & C \\
\hline 6 & AXC \\
\hline 7 & AXC \\
\hline 8 & BXC \\
\hline 9 & e \\
\hline 10 & e \\
\hline 11 & BXC \\
\hline 12 & e \\
\hline 13 & e \\
\hline
\end{tabular}

Penempatan faktor utama dan interaksi diatas didasarkan pada kaidah linear graphs dan tabel segitiga interaksi, sementara itu kolom yang kosong (e) tidak mempengaruhi hasil pengamatan dan tetap terjaga orthogonalitasnya.

\section{Analisis Varian Satu Arah}

Analisis Varian adalah teknik yang digunakan untuk memcahkan total variasi eksperimen ke dalam sumber-sumber variasi yang diamati. Tabel Anova satu arah dapat ditunjukkan sebagai berikut :

Tabel 3. ANOVA Satu Arah

\begin{tabular}{|l|c|c|c|c|}
\hline \multicolumn{1}{|c|}{ Sumber Variasi } & $\mathrm{DB}$ & $\mathrm{SS}$ & $\mathrm{MS}$ & $\mathrm{F}_{\text {hitung }}$ \\
\hline Pelakuan & $\mathrm{V}_{\mathrm{A}}$ & $\mathrm{SS}_{\mathrm{A}}$ & $\mathrm{MS}_{\mathrm{A}}$ & $\mathrm{MS}_{\mathrm{A}} / \mathrm{MS}_{\mathrm{e}}$ \\
Residual & $\mathrm{V}_{\mathrm{e}}$ & $\mathrm{SS}_{\mathrm{B}}$ & $\mathrm{MS}_{\mathrm{e}}$ & \\
\hline Total & $\mathrm{V}_{\mathrm{T}}$ & $\mathrm{SS}_{\mathrm{T}}$ & & \\
\hline
\end{tabular}




\section{BAHAN DAN CARA KERJA \\ Bahan Penelitian}

Dies pada umumnya dituntut memiliki kekerasan yang tinggi, sehingga bahan yang cocok untuk dies adalah baja karbon tinggi. Proses pengerjaan baja karbon tinggi dengan proses konvensional biasanya tidak menguntungkan karena dituntut tool (alat) dengan bahan yang mempunyai kekerasan yang lebih tinggi dari baja karbon tinggi terlebih kalu dies tersebut mempunyai kontur yang berbentuk komplek.sehingga pengerjaan dengan EDM sangat membantu. Baja yang sering dikerjakan dan digunakan di PT. Hay-SEN adalah baja karbon jenis SKD 11. Dalam pengerjaannya elektrode yang sering digunakan adalah tembaga, sehingga pada penelitian ini digunakan bahan yang digunakan yaitu untuk benda kerja digunkan jenis SKD 11 dan elektrode yang digunakan adalah tembaga.

\section{Peralatan}

Peralatan yang digunakan sebagai berikut :

1. Mesin EDM type CHMER 50MP.

2. Peralatan ukur

a. Surface roughness tester

b. Mister ingsut jam

c. Neraca digital

d. Stop watch

\section{Pengumpulan Data}

Data yang digunakan adalah data sekunder yang didapat dari percobaan di PT.HAY SEN.

\section{Variabel Penelitian}

Pada penelitian ini digunakan arus listrik, tegangan dan on time pulse sebagai variabel bebas serta tiga variabel respon yang diamati dan menjadi tujuan perbaikan kualitas. Ketiga variabel respon tersebut adalah :
a. Laju Keausan Pahat
b. Kekerasan permukaan
c. Ketelitian dimensi

Adapun variabel bebas yang diambil pada penelitian ini adalah variabel dari proses permesinan pada mesin EDM. Variabel tersebut adalah sebagai berikut :

- Kuat arus listrik dalam ampere

- Ontime Pulse

- Tegangan Listrik

\section{Rancangan Percobaan}

Untuk memperoleh kombinasi level variabel yang menghasilkan respon yang optimum pada proses pembuatan dies dengan proses EDM digunakan rancangan percobaan Taquchi dengan Orthogonal Arraynya. Untuk memilih Orthogonal Array yang digunakan, maka harus ditentukan derajat kebebasan total dari variabel yang digunakan. Besarnya derajat bebas total dari suatu percobaan tergantung pada :

1. Jumlah variabel bebas yang digunakna dalam percobaan tersebut.

2. Jumlah taraf dari masing-masing variabel bebas. 
Orthogonal array yang digunakan adalah orthogonal yang memiliki minimal 10 baris, untuk itu dipilih $\mathrm{L}_{18}$. Karena pada orthogonal array $\mathrm{L}_{18}$ tidak memuat adanya interaksi linear graph maka digunakan orthogonal array $\mathrm{L}_{27}$.

\section{Prosedur Penelitian}

1. Menetapkan rancangan percobaan utama yaitu rancangn $\mathrm{OA}_{27}$

2. Mengatur penempatan kolom

3. Melaksanakan percobaan utama

4. Mentransformasi data pengamatan ke bentuk rasio signal to noise $(\mathrm{S} / \mathrm{N})$

5. Melakukan analisis varian terhadap respon

6. Melakukan pooling

7. Melakukan analisis residual

8. Menguji efek non-linieritas

9. Menghitung persen kintribusi masing-masing faktor terhadap respon

10. Menentukan kombinasi optimum

11. Menghitung nilai taksiran respon pada setting yang optimum

12. Menentukan setting terbaikyang dapat menghasilkan kondisi optimum pada ketiga respon secara sekaligus melalui aplikasi prosedur TOPSIS

13. Melakukan eksperimen konfirmasi untuk mengetahui apakah setting optimum telah diperoleh benar-benar menghasilkan peningkatan kualitas pada ketiga respon.

\section{HASIL DAN PEMBAHASAN Percobaan Utama}

Percobaan utama ini dilakukan berdasarkan hasil referensi yang ada yang menunjukkan bahwea informasi deduktif mengenai interaksi antar faktor utama dalam penelitian ini telah diperoleh. Berdasarkan informasi dari perusahaan yang menyatakan bahwa interaksi dua faktor AXC berpengaruh secara signifikan terhadap ketiga respon secara bersama. Oleh karena itu rancangan percobaan yang dipilih dalam penelitian ini mengikutsertakan pengaruh interaksi dua faktor.

\section{Analisis Data dan Pembahasan Respon Laju Keausan Elektrode}

Variabel terikat yang satu ini mempunyai karakteristik kualitas lebih kecil lebih baik (small is better) yang artinya semakin kecil laju keausan elektrode, semakin disukai. Faktor-faktor yang akan diuji apakah berpengaruh secara signifikan terhadap laju keausaunbakn elektrode dengan ANOVA dua arah adalah kuat arus (A), on-time pulse (B), tegangan (C) dan interaksi arus dengan tegangan (AXC) yang dapat dimodelkan sebagai berikut :

$$
Y_{i j k l}=\mu+\alpha_{i}+\beta_{j}+\gamma_{k}+\alpha \gamma_{i k}+\varepsilon_{i j k l}
$$

Dimana :

$Y_{i j k l}=$ Kondisi laju keausan elektrode pada faktor A taraf ke-i, faktor B taraf ke-

J, faktor C taraf ke-k dan interaksi AXC.

$\mu \quad=$ rata-rata keseluruhan

$\alpha_{i} \quad=$ pengaruh faktor $\mathrm{A}$ taraf ke-i

$\beta_{j} \quad=$ pengaruh faktor $\mathrm{B}$ taraf ke- $\mathrm{j}$

$\gamma_{k}=$ pengaruh faktor $\mathrm{C}$ taraf ke-k 


$$
\begin{aligned}
& \alpha \gamma_{i k}=\text { pengaruh interaksi faktor AXC } \\
& \varepsilon_{i j k l}=\text { error } \sim \operatorname{IIDN}\left(0, \sigma^{2}\right)
\end{aligned}
$$

Pengujian hipotesis dan kesimpulan yang dapat diambil dari tabel ANOVA diatas adalah sebagai berikut :

a. Ho : $\alpha_{1}=\ldots=\alpha_{3}=0$ (tidak ada efek faktor kuat arus)

H1 : paling sedikit ada satu pasang $\alpha_{1}$ yang tidak sama.

Kesimpulan : $F_{\text {hitung }}=134.21>F_{(10 \%, 2,14)}=2.67$ maka menolak Ho, yaitu ada pengaruh perbedaan level dari kuat arus pada variabel respon laju keausan elektrode.

b. Ho : $\beta_{1}=\ldots=\beta_{3}=0$ (tidak ada efek faktor on-time pulse).

H1 : paling sedikit ada satu pasang $\beta_{1}$ yang tidak sama.

Kesimpulan : $F_{\text {hitung }}=83.41>F_{(10 \%, 2,14)}=2.67$ maka menolak Ho, yaitu terdapat pengaruh perbedaan level dari on-time pulse pada variabel respon laju keausan elektrode.

c. Ho : $\gamma_{1}=\ldots=\gamma_{3}=0$ (tidak ada efek faktor tegangan).

H1 : paling sedikit ada satu pasang $\gamma_{k}$ yang tidak sama.

Kesimpulan : $F_{\text {hitung }}=7.83>F_{(10 \%, 2,14)}=2.67$ maka menolak Ho, yaitu terdapat pengaruh perbedaan level dari tegangan pada variabel respon laju keausan elektrode.

d. Ho : $\alpha \gamma_{11}=\ldots=\alpha \gamma_{33}=0$ (tidak ada efek interaksi arus dan tegangan)

H1 : paling sedikit ada satu pasangan $\alpha \gamma_{i k}$ yang tidak sama.

Kesimpulan : $F_{\text {hitung }}=3.76>F_{(10 \%, 2,14)}=2.67$ maka menolak Ho, yaitu ada pengaruh perbedaan level dari interaksi antara arus dan tegangan pada variabel respon laju keausan elektrode.

\section{Kondisi Optimum Laju Keausan Elektrode}

Kondisi optimum untuk respon Laju keausan elektrode dicapai pada kombinasi level $A_{1} B_{3} C_{3}$,yaitu:

$\begin{array}{ll}\text { Kuat Arus } & : 3 \mathrm{~A} \\ \text { On-time Pulse } & : 800 \mu \mathrm{s} \\ \text { Tegangan } & : 90 \text { Volt }\end{array}$

\section{Analisis Data dan Pembahasan Respon Kekasaran Permukaan}

Respon kekasaran permukaan dinyatakan dengan besaran $\mu \mathrm{m}$. Karakteristik kulaitas yang berkenaan dengan kekasaran permukaan adalah lebih kecil lebih baik. Faktor-faktor yang akan diuji apakah berpengaruh secara signifikan terhadap respon kekasaran permukaan adalah kuat arus (A), on-time pulse (B), tegangan (C), dan interaksi AXC yang dapat dimodelkan sebagai berikut :

$$
Y_{i j k l}=\mu+\alpha_{i}+\beta_{j}+\gamma_{k}+\alpha \gamma_{i k}+\varepsilon_{i j k l}
$$

Dimana :

$Y_{i j k l}=$ Kondisi laju keausan elektrode pada faktor A taraf ke-i, faktor B taraf ke$\mathrm{J}$, faktor C taraf ke-k dan interaksi BXD. 
$\mu \quad=$ rata-rata keseluruhan

$\alpha_{i} \quad=$ pengaruh faktor $\mathrm{A}$ taraf ke- $\mathrm{i}$

$\beta_{j} \quad=$ pengaruh faktor $\mathrm{B}$ taraf ke- $\mathrm{j}$

$\gamma_{k}=$ pengaruh faktor $\mathrm{C}$ taraf ke-k

$\alpha \gamma_{i k}=$ pengaruh interaksi faktor BXD

$\varepsilon_{i j k l}=$ error $\sim \operatorname{IIDN}\left(0, \sigma^{2}\right)$

Maka dilakukan pengujian sebagai berikut :

a. Ho : $\alpha_{1}=\ldots=\alpha_{3}=0$ (tidak ada efek faktor kuat arus)

H1 : paling sedikit ada satu pasang $\alpha_{1}$ yang tidak sama.

Kesimpulan : $F_{\text {hitung }}=208.05>F_{(10 \%, 2,14)}=2.67$ maka menolak Ho, yaitu ada pengaruh perbedaan level dari kuat arus pada variabel respon kekasaran permukaan.

b. Ho : $\beta_{1}=\ldots=\beta_{3}=0$ (tidak ada efek faktor on-time pulse).

H1 : paling sedikit ada satu pasang $\beta_{1}$ yang tidak sama.

Kesimpulan : $F_{\text {hitung }}=83.41>F_{(10 \%, 2,14)}=2.67$ maka menolak Ho, yaitu terdapat pengaruh perbedaan level dari on-time pulse pada variabel respon kekasaran permukaan.

c. Ho : $\gamma_{1}=\ldots=\gamma_{3}=0$ (tidak ada efek faktor tegangan).

H1 : paling sedikit ada satu pasang $\gamma_{k}$ yang tidak sama.

Kesimpulan : $F_{\text {hitung }}=7.83>F_{(10 \%, 2,14)}=2.67$ maka menolak Ho, yaitu terdapat pengaruh perbedaan level dari tegangan pada variabel respon kekasaran permukaan.

d. Ho : $\alpha \gamma_{11}=\ldots=\alpha \gamma_{33}=0$ (tidak ada efek interaksi arus dan tegangan)

H1 : paling sedikit ada satu pasangan $\alpha \gamma_{i k}$ yang tidak sama.

Kesimpulan : $F_{\text {hitung }}=3.76>F_{(10 \%, 2,14)}=2.67$ maka menolak Ho, yaitu ada pengaruh perbedaan level dari interaksi antara arus dan tegangan pada variabel respon kekasaran permukaan.

\section{Kondisi Optimum Kekasaran Permukaan}

Pengaruh faktor utama terlihat pada kondisi optimum untuk respon Laju keausan elektrode dicapai pada kombinasi level $A_{1} B_{1} C_{1}$, sehingga dengan mengikutsertakan interaksi maka kombinasi level yang dicapai yaitu:
Kuat Arus
$: 3 \mathrm{~A}$
On-time Pulse
$: 100 \mu \mathrm{s}$
Tegangan
: 70Volt

\section{Analisis Data dan Pembahasan Respon Ketelitian Dimensi}

Respon ketelitian dimensi dinyatakn dengan besarnya penyimpangan ukuran material hasil dari proses EDM terhadap ukuran yang sebenarnya. Karakteristik kualitas yang berkenaan dengan ketelitian dimensi adalah lebih kecil lebih baik. Faktor-faktor yang akan diuji apakah berpengaruh secara signifikan terhadap 
respon ketelitian dimensi adalah kuat arus (A), on-time pulse (B), tegangan (C), dan interaksi AXC yang dapat dimodelkan sebagai berikut :

$$
Y_{i j k l}=\mu+\alpha_{i}+\beta_{j}+\gamma_{k}+\alpha \gamma_{i k}+\varepsilon_{i j k l}
$$

Dimana :

$Y_{i j k l}=$ harga ketelitian dimensi pada kuat arus taraf ke-i, tegangan taraf ke-J, ontime pulse taraf ke-k dan interaksi AXC.

$\mu \quad=$ rata-rata keseluruhan

$\alpha_{i} \quad=$ pengaruh faktor $\mathrm{A}$ taraf ke- $\mathrm{i}$

$\beta_{j} \quad=$ pengaruh faktor $\mathrm{B}$ taraf ke- $\mathrm{j}$

$\gamma_{k}=$ pengaruh faktor $\mathrm{C}$ taraf ke-k

$\alpha \gamma_{i k}=$ pengaruh interaksi faktor BXD

$\varepsilon_{i j k l}=$ error $\sim \operatorname{IIDN}\left(0, \sigma^{2}\right)$

Maka dilakukan pengujian sebagai berikut :

e. Ho : $\alpha_{1}=\ldots=\alpha_{3}=0$ (tidak ada efek faktor kuat arus)

H1 : paling sedikit ada satu pasang $\alpha_{1}$ yang tidak sama.

Kesimpulan : $F_{\text {hitung }}=208.05>F_{(10 \%, 2,14)}=2.67$ maka menolak Ho, yaitu ada pengaruh perbedaan level dari kuat arus pada variabel respon ketelitian dimensi.

f. Ho : $\beta_{1}=\ldots=\beta_{3}=0$ (tidak ada efek faktor on-time pulse).

H1 : paling sedikit ada satu pasang $\beta_{1}$ yang tidak sama.

Kesimpulan : $F_{\text {hitung }}=83.41>F_{(10 \%, 2,14)}=2.67$ maka menolak Ho, yaitu terdapat pengaruh perbedaan level dari on-time pulse pada variabel respon ketelitian dimensi.

g. Ho : $\gamma_{1}=\ldots=\gamma_{3}=0$ (tidak ada efek faktor tegangan).

H1 : paling sedikit ada satu pasang $\gamma_{k}$ yang tidak sama.

Kesimpulan : $F_{\text {hitung }}=7.83>F_{(10 \%, 2,14)}=2.67$ maka menolak Ho, yaitu terdapat pengaruh perbedaan level dari tegangan pada variabel respon ketelitian dimensi.

h. Ho : $\alpha \gamma_{11}=\ldots=\alpha \gamma_{33}=0$ (tidak ada efek interaksi arus dan tegangan)

$\mathrm{H} 1$ : paling sedikit ada satu pasangan $\alpha \gamma_{i k}$ yang tidak sama.

Kesimpulan : $F_{\text {hitung }}=3.76>F_{(10 \%, 2,14)}=2.67$ maka menolak Ho, yaitu ada pengaruh perbedaan level dari interaksi antara arus dan tegangan pada variabel respon ketelitian dimensi.

\section{Kondisi Optimum Ketelitian Dimensi}

Sehingga dengan mengikutsertakan interaksi maka kombinasi level yang dicapai pada $A_{1} B_{1} C_{1}$, yaitu:

Kuat Arus $\quad: 3 \mathrm{~A}$

On-time Pulse $\quad: 100 \mu \mathrm{s}$

Tegangan : :70Volt 


\section{Analisis Data dan Pembahasan dengan Prosedur TOPSIS}

Kombinasi level faktor yang dapat mengoptimalkan masing-masing respon tersebut adalah sebagai berikut:

- Laju Keausan Elektrode

$$
\begin{array}{ll}
\text { - Laju Keausan Elektrode } & : A_{1} B_{3} C_{3} \\
\text { - Kekasaran Permukaan } & : A_{1} B_{1} C_{1} \\
\text { - Ketelitian Dimensi } & : A_{1} B_{1} C_{1}
\end{array}
$$

Dengan menggunakan prosedur TOPSIS akan diperoleh level kuat arus, tegangan, on time pulse, serta interaksi arus dan tegangan yang dapat mengoptimalkan ketiga respon tersebut.

Untuk mencapi suatu setting yang dapat mengoptimumkan ketiga rsspon secara sekaligus, digunakan metode Taguchi dengan pendekatan non-konvensional, yaitu pendekatan prosedur TOPSIS untuk menyelesaikan masalah-masalah Taguchi Multirespon

\section{Kombinasi Optimum}

Kombinasi kondisi perlakuan yang dapat menghasilkan kualitas optimum pada ketiga respon secara sekaligus diperoleh dengan cara menghitung nilai TOPSIS. Berdasarkan nilai-nilai TOPSIS yang diperoleh, dapat dilihat pengaruh dari faktor-faktor utama terhadap nilai TOPSI. Nilai TOPSIS yang tertinggi menggambarkan kualitas yang baik, oleh karena itu kombinasi optimum dicapai pada nilai TOPSIS tertinggi tiap taraf faktor yaitu $A_{1}, B_{3}, C_{1}$ yang merupakan kombinasi dari :

$\begin{array}{ll}\text { Kuat Arus } & : 3 \mathrm{~A} \\ \text { On-Time Pulse } & : 800 \mu \mathrm{s} \\ \text { Tegangan } & : 70 \text { Volt }\end{array}$

Berdasarkan tabel diatas dapat diketahui bahwa faktor tegangan mempunyai konstribusi pengaruh yang paling besar terhadap nilai TOPSIS, diikuti berturutturut oleh faktor On-Time Pulse dan Arus.

\section{Percobaan Konfirmasi}

Kondisi yang digunakan pada percobaan konfirmasi ini adalah setting A1, B3, C1 yang dtelah diperoleh melalusi prosedur TOPSIS dan dilakukan pengulangan sebanyak enam kali untuk masing-masing kombinasi perlakuan. Hasil percobaan konfirmasi kemudian dibandingkan dengan hasil pada setting awal, yaitu setting yang selama ini dianggap sebagai setting terbaik oleh operator mesin EDM sebagai berikut : A1, B1, C1. Berdasarkan hasil perhitungan menunjukkan bahwa kombinasi optimum yang diperoleh melalui metode Taguchi dengan pendekatan prosedur TOPSIS (Technique for Order Preference by Similarity to Ideal Solution) telah terbukti dapat meningkatkan kualitas hasil pembuatan dies untuk ketiga rspon dalam satu setting A1 B3 $\mathrm{C} 1$, yaitu arus 3 ampere, on-time pulse $800 \mu$ s dan tegangan 70 volt.

\section{E. KESIMPULAN DAN SARAN \\ Kesimpulan}

Berdasarkan hasil dan pembahasan serta tujuan yang telah diuraikan diatas, maka dapat diambil beberapa kesimpulan antara lain: 
1. Respon ketelitian Dimensi, Kekasaran Permukaan dan Laju Keausan Elektrode dipengaruhi secara signifikan oleh faktor-faktor Arus, On-Time Pulse dan Tegangan dimana terdapat interaksi antar dua faktor utama (Arus dengan tegangan) yang berpengaruh secara signifikan terhadap ketiga respon sekaligus.

2. Kombinasi taraf faktor untuk seting permesinan EDM yang dapat menghasilkan respon ketelitian dimensi, Kekasaran Permukaan dan Laju keasusan elketrode yang optimun secara sekaligus adalah :
- Arus
$: 3 \mathrm{~A}$
- On Time Pulse : $800 \mu \mathrm{s}$
- Tegangan
: 70 Volt

3. Taksiran harga ketelitian dimensi yang optimum adalah sebesar $0.0354 \mathrm{~mm}$. Dengan interval kepercayaan 90\%, hasil ini mempunyai range antara 0.0325 mm sampai $0.0387 \mathrm{~mm}$. dan untuk kekasaran permukaan yang optimum adalah sebesar $1.24 \mu \mathrm{m}$. Dengan interval kepercayaan 90\%, maka diperoleh range antara $0.0078 \mathrm{~mm} 3 /$ detik sampai $0.0118 \mathrm{~mm} 3 /$ detik.

\section{Saran}

1. Agar didapatkan kondisi optimum yang lebih global (dapat bersifat kontinu) maka disarankan untuk menggunakan metode response surface.

2. Perlu sekali dilakukan perbandingan $\mathrm{S} / \mathrm{N}$ Taguchi dengan Respon Surface dalam satu eksperimen.

\section{DAFTAR PUSTAKA}

Draper Norman R and Smith Harry, "Analisis Regresi Terapan", PT. gramedia pustaka utama, jakarta, edisi ke dua, 1992.

Bagiasna, Komang, "Proses-proses Permesinan Non Konvensional", Diktat Teknologi Mekamik II, ITB,1987.

Montgomery, D.C, "Design and Analysis of Experiment", John Willy And Son, New York, 1976.

Bagchi, Tapan, "Taguchi Methods Explained Practical Steps To Robust Design", Prentice Hall, Kanpus, 1993.

Ross, P.J,. "Taguchi Techniques For Quality Engineering”, Mc Graw-Hill, New York, 1989.

Rochim, Taufik, "Spesifikasi, Metrologi dan Kontrol Kualitas Geometri", ITB, Bandung, 1985.

Degarmo, P.E, Block, J.T, Kohser, R.A, "Material and Process In Manufacturing", Eighth Edition, Prentice Hall, New Jersey, USA, 1997.

Pandey, P.C, Shan, H.S, "Modern Machining Processes", Second Edition, Tata Mc Graw-Hill, New Delhi, 1983.

Tong, L. And Chao, T., "Optimizing Multi-Respon Problems In The Taguchi Methods By Fuzzy Multiple Attribute Decision Making”, Quality and Reability, Engineering International, Vol 13, 25-34, 1997.

Roy, Rajit K, “A Primer On The Taguchi Methode", Van Nostrand Renhold, New York, 1990. 
